\title{
Liver Regeneration after Liver Transplantation
}

\author{
A. Taki-Eldin L. Zhou H.-Y.Xie S.-S. Zheng \\ Key Laboratory of Combined Multi-Organ Transplantation, Ministry of Public Health, First Affiliated Hospital, \\ Zhejiang University School of Medicine, Hangzhou, China
}

\section{Key Words}

Liver regeneration · Transplantation · Cytokines · Growth factors • Graft size

\begin{abstract}
Background/Purpose: The liver has a remarkable capacity to regenerate after injury or resection. The aim of this review is to outline the mechanisms and factors affecting liver regeneration after liver transplantation. Methods: Relevant studies were reviewed using Medline, PubMed and Springer databases. Results: A variety of cytokines (such as interleukin- 6 and tumor necrosis factor- $\alpha$ ), growth factors (like hepatocyte growth factor and transforming growth factor- $\alpha$ ) and cells are involved in liver regeneration. Several factors affect liver regeneration after transplantation such as ischemic injury, graft size, immunosuppression, steatosis, donor age and viral hepatitis. Conclusion: Liver regeneration has been studied for many years. However, further research is essential to reveal the complex processes affecting liver regeneration, which may provide novel strategies in the management of liver transplantation recipients and donors.

Copyright $\odot 2012$ S. Karger AG, Basel
\end{abstract}

\section{Introduction}

The liver is an important organ within the body that has a central role in metabolic homeostasis as it is responsible for the metabolism, synthesis, storage and redistribution of nutrients, carbohydrates, fats and vitamins [1]. The liver produces large numbers of serum proteins including albumin and acute-phase proteins, enzymes and cofactors. Importantly, it is the main detoxifying organ of the body, which removes wastes and xenobiotics by metabolic conversion and biliary excretion [2].

Hepatic regeneration following resections or injury involving less than $70 \%$ of total liver mass proceeds uneventfully until restitution of the original liver mass is complete, often within 3-6 months in an otherwise healthy human liver [3].

The amazing regenerative capacity of the liver is most clearly shown by the two-thirds partial hepatectomy (PH) model in rodents, which was pioneered by Higgins and Anderson [4] in 1931. In this model, two thirds of the liver is surgically removed, and the remaining liver enlarges until the original liver mass is restored within 5-7 days after surgery.

Regenerative activity is proportional to the regenerative stimulus until $70 \%$ of the liver has been resected or

\section{KARGER}

Fax +41613061234

E-Mail karger@karger.ch

www.karger.com
(C) 2012 S. Karger AG, Basel

0014-312X/12/0483-0139\$38.00/0

Accessible online at: www.karger.com/esr
Shu-Sen Zheng, MD, PhD, FACS

Key Laboratory of Combined Multi-Organ Transplantation

Ministry of Public Health, First Affiliated Hospital

Zhejiang University School of Medicine, Hangzhou 310003 (China)

Tel. +8657187236567, E-Mail shusenzheng@zju.edu.cn 
destroyed. Thereafter, there is a marked decline (but not to baseline levels) in regenerative activity despite increased stimulation [5].

Hepatic resection is safely accomplished for malignant and benign disease because of the ability of the liver to regain its functional mass in a matter of days or weeks. Liver regeneration is a very complex process involving the activation and interaction of multiple cytokines and growth factors that regulate cell growth and proliferation. Simultaneously, liver cells continue to function while undergoing mitosis in order to reestablish the organ's mass and architecture [6].

This amazing regenerative capacity of the liver after hepatic resection has recently become even more significant with the advent of new techniques and procedures in liver transplantation [7].

Regeneration is crucial in liver transplantation. In cadaveric transplantation, hepatocyte loss occurs due to (1) ischemia/reperfusion injury which is inevitable because of the necessary preservation period from procurement to implantation, regenerative mechanisms are actively engaged after transplantation depending on the length and degree of the cold ischemic injury, and (2) the alloimmune response require replacement [8].

Regeneration is also critically required in the setting of living donor liver transplantation (LDLT) because even though the ischemic injury is minimized in LDLT, as the preservation period is very short, this technique supplies a graft, which is by definition too small, by transplanting only $50-60 \%$ of the expected liver volume in adults; this requires vigorous immediate hepatocyte proliferation. Both the recipients and the donors must rely on the rapid regeneration of a partial liver in addition to maintaining the basic metabolic functions of the liver [7].

The remarkable increase in the number of cases of liver transplantation, especially LDLT, in recent years has brought the topic of liver regeneration after liver transplantation to the forefront.

\section{Molecular and Cellular Characteristics of Liver Regeneration}

Cell division is rarely seen in hepatocytes in the normal adult liver, as these cells are in the G0 phase of the cell cycle. However, after PH approximately $95 \%$ of hepatic cells, which are normally quiescent, rapidly reenter the cell cycle [9].
Individual hepatocytes have an amazing replicative capacity, as only a few hepatocytes are required to restore liver mass after profound liver injury $[10,11]$.

Early studies in rodent models show that after $\mathrm{PH}$, hepatocytes begin to replicate within $24 \mathrm{~h}$, with biliary epithelial cells and Kupffer cells replicating soon after [9].

All evidence to date has shown that the fully differentiated hepatocyte is the replicating cell that accounts for the rapid regeneration after $\mathrm{PH}$ [12].

In the normal adult rat, the turnover rate is approximately one mitosis per year, but $\mathrm{PH}$ greatly stimulates the rate of mitosis. Liver weight doubles in $48 \mathrm{~h}$ reaching a normal size in 5-7 days, although regeneration continues for 15-16 days. A bust of DNA synthesis in hepatocytes begins $15-18 \mathrm{~h}$ after $\mathrm{PH}$ - as they enter the $\mathrm{S}$ phase of cell cycle - and reaches a peak in $24 \mathrm{~h}$ and then declines. A second but lower maximum is reached at about $56 \mathrm{~h}$. However, the induction of DNA synthesis occurs later in the nonparenchymal cells (at about $48 \mathrm{~h}$ for Kupffer and biliary epithelial cells, and at about $96 \mathrm{~h}$ for endothelial cells). Subsequent levels of DNA synthesis in hepatocytes are lower, as complete restoration of liver mass requires an average of approximately 1.6 cycles of replication in all cells. By comparison, the peak in DNA synthesis in mice occurs later (36-40 h after $\mathrm{PH}$ ) and varies between strains. The onset of DNA synthesis is well synchronized in hepatocytes, beginning in cells that surround the portal vein of the liver lobule and proceeding towards the central vein. Regenerating hepatocytes may divide more rapidly than their capacity to reestablish a sinusoidal pattern and thus maintain the liver plate-sinusoid plate relationship. Rapidly generating hepatocytes are swollen and hydrophilic compared with normal hepatocytes, their nuclei are enlarged with more crisply defined chromatin, and nucleoli are prominent. The functional capacity of effectively regenerating hepatocytes is diminished compared with that of normal hepatocytes. The regenerative response involves hypertrophy and hyperplasia $[2,13]$.

Liver regeneration after $\mathrm{PH}$ is carried out by proliferation of all the existing mature cellular populations composing the intact organ. These include hepatocytes, biliary epithelial cells, Kupffer cells and stellate cells. All of these cells proliferate to rebuild the hepatic tissue $[14,15]$.

In addition to the highly differentiated cells that can readily proliferate, there is also a secondary proliferative compartment within the liver composed of the intrahepatic stem and progenitor cells, which constitutes a functional segment of the biliary system. Oval cells are thought to be the progeny of these cells, and in models of liver in- 
jury, caused by the administration of $\mathrm{D}$-galactosamine, acetyl aminofluorene, dipin or the combination of carbon tetrachloride $\left(\mathrm{CCl}_{4}\right)$ administration and $\mathrm{PH}$, regeneration seems to be quite dependent on the proliferation and differentiation of oval cells $[16,17]$. These cells, however, are not present in $\mathrm{PH}$ models without injury $[12,18]$.

Liver repopulation and transplantation studies indicate that bone marrow stem cells might have the capacity to differentiate into hepatocytes, but it is unclear whether this transition is a rare event or the normal means by which the liver replenishes its hepatocyte pool when faced with certain types of injury. However, other studies have indicated that rare cell fusion events between bone marrow stem cells and hepatocytes could give the appearance that the resulting cells are derived from bone marrow stem cells when they are, in fact, of hepatocyte origin [2, $19,20]$.

On a molecular level, studies in the past decade have elucidated cytokine pathways, transcriptional regulation and patterns of gene activation after $\mathrm{PH}$ in animal models. These cascades are initiated within minutes to hours after $\mathrm{PH}$ [7].

It has become increasingly apparent that specific cytokines [tumor necrosis factor (TNF)- $\alpha$, interleukin (IL)6], growth factors [hepatocyte growth factor (HGF), transforming growth factor (TGF)- $\alpha$ ], and transcription factors [nuclear factor (NF)- $\kappa$, signal transducer and activator of transcription (STAT3), AP-1 (activator protein-1), C/EBP $\beta$ (CCAAT/enhancer-binding protein $\beta$ ) and Foxm 1B] play an important role in the initiation and maintenance of liver regeneration [21].

Previous studies suggest that tri-iodothyronine $\left(\mathrm{T}_{3}\right)$ regulates liver regeneration after a $70 \%$ partial hepatectomy in the albino rat [22]. Insulin and glucagons also have a potential role in liver regeneration [23].

In animal models, in which hepatocytes are directly damaged and thereby induced to undergo necrosis, similar growth factor-mediated and cytokine-mediated pathways are activated as occurs after PH. Proliferation of hepatocytes is also involved in liver regeneration that occurs after massive hepatocyte necrosis, or apoptosis that is induced by hepatic toxins such as $\mathrm{CCl}_{4}$ or a systemically introduced Fas ligand, but the cell cycle response is not as synchronized [24, 25].

There are also significant changes in liver architecture during liver regeneration, both after $\mathrm{PH}$ and liver necrosis. The size of the liver lobules is remarkably larger and the thickness of the hepatocyte plates is almost twice the size of the normal cell thickness. Previous studies suggest that slow lobular reorganization is taking place for sev-

Liver Regeneration after Transplantation eral weeks, and eventually liver histology becomes indistinguishable from the original $[2,26]$.

\section{Initiation of Liver Regeneration}

For regeneration to take place, the hepatocytes must gain proliferative capacity to enter the cell cycle and respond to other growth factors such as HGF, TGF- $\alpha$, and heparin-binding epidermal growth factor, a process referred to as 'priming' [27].

A wide variety of genes are differentially expressed during the first few hours after $\mathrm{PH}$ (the priming phase); many of these genes are involved in the cytokine network like TNF- $\alpha$ and IL-6 [28-30]. The important role of TNF$\alpha$ and IL- 6 in triggering the regeneration was proven by the inhibition of DNA replication by anti-TNF antibodies [28], the blockage of liver regeneration in IL-6 and TNF receptor type I (TNF-R1) knockout (KO) mice [31, 32], and the correction of the defect in TNF-R1 KO mice by an IL-6 injection [32].

Lipopolysaccharide (LPS), a component of the innate immune system that interacts with the LPS receptor on Kupffer cells, is important in triggering liver regeneration after $\mathrm{PH}$ and in other models of liver injury through stimulation of the production of inflammatory chemokines and cytokines, including IL- 6 and TNF- $\alpha[33,34]$. Moreover, members of the complement cascade, C3a and C5a, interact with their receptors on Kupffer cells to stimulate IL- 6 and TNF- $\alpha$ release [35].

Extracellular matrix remodeling after $\mathrm{PH}$ plays an important role in the initiation of liver regeneration by altering the balance between mitogens and mitoinhibitors by causing release (local and circulatory) and activation of HGF while releasing TGF- $\beta_{1}$ extensively in the circulation, where TGF- $\beta_{1}$ is bound and inactivated by $\alpha_{2}$-macroglobulin $[26,36]$.

Other events, like the expression of $\beta$-catenin [37] and the Notch-1 intracellular domain [38] in hepatocyte nuclei within 15-30 min after $\mathrm{PH}$, participate in the initiation of regeneration as elimination of the expression of these proteins by RNA interference [38] decreases the regenerative response.

The precise orchestration of all the above-mentioned events is probably required to initiate the regenerative process.

\section{Pathways of Liver Regeneration}

Investigators have been able to elucidate cytokine-dependent and cytokine-independent pathways that are crucial for liver regeneration and connect many of the identified proteins to these pathways $[2,25]$. 


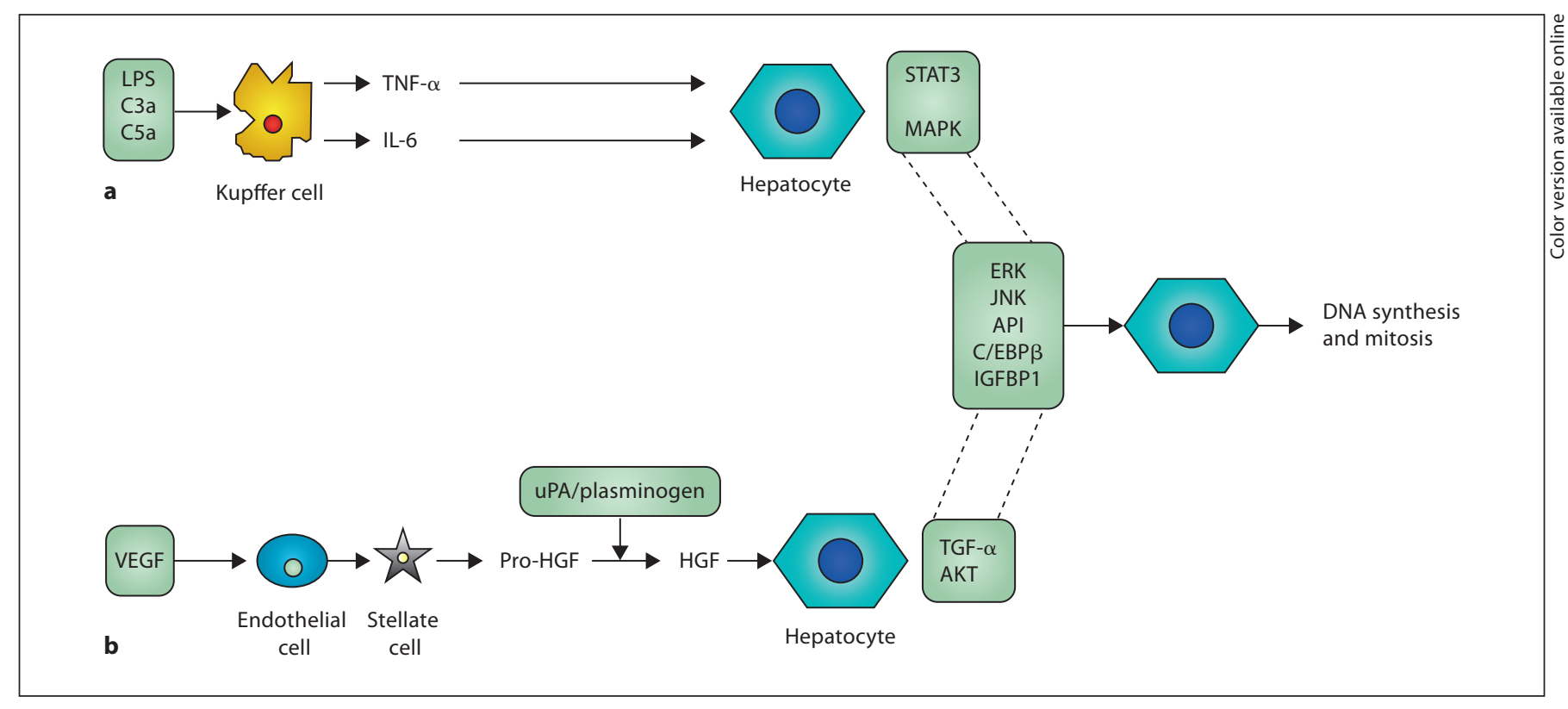

Fig. 1. Pathways of regeneration. a Cytokine-dependent pathway. $\mathbf{b}$ Cytokine-independent pathway. VEGF = Vascular endothelial growth factor; $\mathrm{uPA}=$ urokinase plasminogen activator.

Cytokine-Dependent Pathway

This pathway relies on IL- 6 and TNF- $\alpha$, with some contribution from other cytokines such as IL-1 (fig. 1) [21]. IL-6, previously thought to be only a proinflammatory cytokine, seems to be an essential growth factor in the process of liver regeneration [39]. Mice lacking IL- 6 or the TNF receptor have a blunted DNA response after $\mathrm{PH}$, resulting in liver necrosis and failure. A single dose of recombinant IL- 6 before resection reverses this trend [31,32].

On the other hand, Sakamoto et al. [40] reported that liver regeneration in IL-6-deficient mice is essentially normal even though there is decreased activation of STAT3.

Experimental evidence supports the concept that IL-6 is released from Kupffer cells and followed by a transcriptional cascade which then results in hepatocyte replication [41].

IL- 6 and TNF- $\alpha$ are believed to be released from Kupffer cells in response to an initiating stimulus, such as LPS, within the liver or from an outside environmental stimulus [21].

The binding of IL- 6 to its receptor IL-6R, which is associated with two subunits of gp130, stimulates the tyrosine kinase activity of the associated Janus kinase family member, usually JAK1. Activated JAK then phosphorylates the associated gp130 and STAT3 on a tyrosine resi- due, which results in the dimerization of STAT3. Dimerized STAT3 translocates to the nucleus and activates the transcription of target genes. Stimulation of gp130 also activates the MAPK (mitogen-activated protein kinase) signaling cascade and, although the exact mechanism remains unconfirmed at present, evidence indicates that JAK1 activates the $\mathrm{SH} 2$ domain containing tyrosine phosphatase SHP2 and recruits growth factor receptorbound protein 2/son of sevenless (GRB2-SOS). GRB2SOS activates Ras, which leads to the activation of Ras-MAPK-ERK (extracellular signal-regulated kinase). MAPK signaling is crucial for cellular proliferation. During liver regeneration, therefore, IL- 6 activates two main pathways - through the gp130-IL-6R complex - the STAT3 and MAPK signaling pathways [2].

This process leads to the activation of a vast array of immediate and delayed early genes required for normal liver-specific metabolic functions as well as for regeneration and repair [7].

The conditional KO of gp130 within the liver had less impact on hepatocyte DNA synthesis after hepatectomy than would have been expected on the basis of the phenotypes of IL-6 or STAT3 KO mice. However, defects in cyclin E and cyclin A expression were observed in gp130deleted livers after hepatectomy, which indicates that gp130 is important for normal cell cycle progression [42]. 
STAT3 and NF- $\mathrm{B}$ expression is enhanced $1 \mathrm{~h}$ after $\mathrm{PH}[43,44]$. However, elimination of either of these two signaling molecules does not abrogate the regenerative response, probably due to the existence of redundant pathways which complement for their loss (e.g. STAT1 assuming the role of STAT3) $[26,45,46]$.

However, despite these findings, STAT3 and NF- $\mathrm{B}$ are critical for cells to progress from G1 to $S$ phase and are crucial for activating the c-myc gene, a gene required for cell cycle progression. Cyclins are then upregulated, thus completing the cycle by moving the cell into S phase, and autonomous cellular replication is achieved [7].

TNF- $\alpha$ signaling is also required for a normal proliferative response after $\mathrm{PH}$. This effect seems to be largely mediated by the ability of TNF- $\alpha$ to induce IL- 6 , as treatment with IL-6 corrects the defect in DNA synthesis that occurs in TNF-R1 KO mice that have had a hepatectomy [32]. TNF- $\alpha$ induces the production of IL- 6 by upregulating NF- $\kappa \mathrm{B}$, which activates the transcription of IL-6 [2].

However, the increase of serum TNF- $\alpha$ after PH has not been universally observed, and it appears to be higher in rats than in mice, and even though TNF-R1 KO mice have multiple deficits after $\mathrm{PH}$, they appear to regenerate normally $[47,48]$. These data suggest that TNF itself may not be required because other ligands such as lymphotoxin- $\alpha$ can signal through TNF-R1 [49].

Early in the process, negative feedback mechanisms are in place with the induction of various inhibitory proteins that are important for terminating liver regeneration including TGF- $\beta$, plasminogen activator inhibitor (PAI), suppressor of cytokine signaling-3 (SOCS3) and p27 and other cyclin-dependent kinase inhibitors, which downregulate STAT3 and inhibit the IL- 6 signaling pathway $[2,50]$.

Cytokine-Independent (Growth Factor-Dependent)

Pathway

The cytokine-independent pathway also promotes cellular proliferation during liver regeneration, and is mediated by growth factors or mitogens [21].

HGF and the epidermal growth factor receptor (EGFR) ligand family are important growth factors that drive cell cycle progression during liver regeneration [49].

HGF is produced in the liver and other tissues by nonparenchymal cells, particularly stellate cells, and may act on hepatocytes by a paracrine or an endocrine mechanism. The HGF precursor, pro-HGF, is rapidly activated by proteases - such as urokinase plasminogen activator and its downstream effector plasminogen - after $\mathrm{PH}$ or liver injury (fig. 1). Blocking urokinase plasminogen ac-

Liver Regeneration after Transplantation tivator delays the appearance of HGF and thereby delays liver regeneration, whereas blocking PAI accelerates the release of HGF and thereby accelerates liver regeneration $[51,52]$.

HGF signals through the c-Met receptor, leading to the activation of several downstream pathways including ERK 1/2, PI3K, S6 kinase and AKT [53-55].

HGF regulates various processes in the liver including mitogenesis, motogenesis and morphogenesis as well as being a direct stimulant of hepatocyte proliferation in cultured hepatocytes. HGF/c-Met signaling is important in hepatoprotection from apoptosis and in the enhancement of hepatic repair after liver injury. In addition, HGF and its receptor c-Met are important growth factors in various tissues [51, 54, 56, 57].

The genetic elimination of HGF or its receptor c-Met is associated with embryonic lethality involving abnormalities in many organs, most notably in the placenta, and, in addition, livers of the embryos are smaller than the wild-type controls [58, 59]. Moreover, Huh et al. [57] reported that hepatocyte c-Met-deficient mice had massive mortality after $\mathrm{PH}$. Of all the signals participating in the very early events after $\mathrm{PH}$ the signaling by HGF appears to be the most irreplaceable contributor in liver regeneration [26].

The family of ligands that binds the EGFR includes EGF, TGF- $\alpha$, heparin-binding EGF-like growth factor (HB-EGF) and amphiregulin (AR). EGF is a strong mitogen for hepatocytes in culture and given to intact animals causes hepatocyte proliferation [60]. EGF is continually available to the liver through the portal vein [61]. However, the concentration of EGF in the portal vein after $\mathrm{PH}$ has not yet been evaluated.

Catecholamines, including epinephrine and norepinephrine, rise rapidly in the plasma after $\mathrm{PH}$ and stimulate the production of EGF from Brunner's glands of the duodenum [62]. Norepinephrine also enhances the mitogenic effects of EGF and HGF in hepatocyte cultures and decreases the mitoinhibitory effects of TGF- $\beta_{1}[26,63$, 64].

The expression of TGF- $\alpha$ mRNA, which is very low in the normal liver, increases after $\mathrm{PH}$ and before the onset of DNA replication. The main effect of TGF- $\alpha$ in the liver is the stimulation of hepatocyte proliferation [65].

Transgenic mice that overexpress TGF- $\alpha$ display constitutive hepatocyte proliferation and eventually develop cancer [66]. On the other hand, KO mice lacking TGF- $\alpha$ show no defects in liver regeneration, most probably because of the overlap between various ligands of the EGF family [67]. 
After $\mathrm{PH}, \mathrm{HB}-\mathrm{EGF}$ is expressed earlier than HGF and TGF- $\alpha$, and HB-EGF transgenic mice with liver-targeted production have enhanced liver regeneration [68]. In addition, HB-EGF KO mice have a deficient regenerative response [69], in spite of the fact that this deficiency is partially compensated by an earlier increase in TGF- $\alpha$ expression.

AR also appears to contribute to liver regeneration, as mice deficient in AR have a deficient liver regeneration [70].

Vascular endothelial growth factor interacts with sinusoidal endothelial cells within the liver and causes an increase in HGF production by these cells. This vascular endothelial growth factor-mediated hepatic growth is dependent on the presence of endothelial cells, but the mechanism is unknown and is partially blocked by treatment with HGF antibodies [71].

Interactions between Cytokine-Dependent and Cytokine-Independent Pathways

The cytokine-dependent and cytokine-independent pathways in liver regeneration have been linked via common downstream signal transduction molecules [e.g. ERK and JNK (Jun amino-terminal kinase)], transcription factors (e.g. AP-1 and C/EBP $\beta$ ) and other molecules, e.g. insulin-like growth factor-binding protein 1 (IGFBP1), that seem to be regulated by both growth factors and cytokines (fig. 1). This allows speculation about how the combination of cytokine and growth factor signals might lead to robust liver regeneration and repair after injury or resection $[2,21]$.

For example, both TNF- $\alpha$ and HGF can activate JNK and MAPK-ERK which are crucial regulators of Jun activation, and they can also induce cell proliferation and the expression of cyclin D1, which is an important checkpoint protein in hepatic growth $[72,73]$.

The IL-6/TNF- $\alpha$ and HGF pathways both upregulate the activity of the various homo- and heterodimeric AP-1 transcription factors, including the Jun-Fos heterodimer. AP- 1 activity is required for the activation of a number of proteins that are involved in growth response [74], and the cooperation of AP-1 with STAT3 amplifies the expression of genes in the liver which results in an adaptive response during liver regeneration [75].

Another possible point of intersection between HGF and IL- 6 signals could be the regulation of the IGFBP1 gene. IGFBP1 encodes a promitogenic and hepatoprotective protein that, in vivo, is upregulated by IL- 6 as well as, potentially, by HGF as indicated by in vitro studies [76, 77].
One important linkage between cytokines and growth factors may be the activation of matrix metalloproteinases by cytokines such as TNF- $\alpha$. The activity of several matrix metalloproteinases increases after $\mathrm{PH}$ [78], one of them is called TGF- $\alpha$-converting enzyme (TACE, also known as ADAM17). TNF- $\alpha$ can activate TACE, which in turn cleaves the TGF- $\alpha$ precursor anchored in the cell membrane. The released, active TGF- $\alpha$ binds to the EGFR resulting in the stimulation of cell proliferation in cultured hepatocytes [79]. TACE has also been shown to cleave the precursor forms of cytokines and many EGFR ligands including TGF- $\alpha$, HB-EGF and AR [80].

\section{Termination of Liver Regeneration}

The size of the liver is highly regulated and is controlled by the functional needs of the organism [81].

The most well-known antiproliferative factors within the liver are TGF- $\beta$ and related family members such as activin. TGF- $\beta$ is produced mainly by hepatic stellate cells and during liver regeneration hepatocytes initially become resistant to it $[25,82]$. TGF- $\beta$ inhibits proliferation of hepatocytes in culture [83], suppresses the production of HGF [84], the expression of urokinase and the activation of HGF [85].

With considerable evidence discounting the role of any single cytokine (e.g. TGF- $\beta$ ) being the terminator of regeneration, attention has been paid to other hepatocyte mitoinhibitors.

Extracellular matrix (in the form of exogenously added matrix such as collagen gels or extracts from EHS sarcoma) inhibits cell proliferation and enhances the differentiation of hepatocytes in culture [86].

The extracellular matrix signaling involves integrinlinked kinase [87]. Liver-specific ablation of integrinlinked kinase in mice results in enhanced proliferation of hepatocytes and biliary cells and hepatomegaly in the absence of $\mathrm{PH}$ [88]. Moreover, liver-specific ablation of integrin-linked kinase in mice results in enhanced liver regeneration after $\mathrm{PH}$ and the liver did not properly terminate its growth at the end of regeneration but continued to grow, reaching a size which is $58 \%$ greater than the original liver [89].

It is reasonable to speculate that the reassembly of the extracellular matrix and the sinusoidal capillary network provides matrix-driven signaling that terminates the regenerative process. This may be direct signaling through integrins or signaling induced by TGF- $\beta$ (bound to the newly synthesized decorin and exerting a tonic mitoinhibitory effect). Newly synthesized matrix would also be capable of binding HGF (a protein with high affinity to 


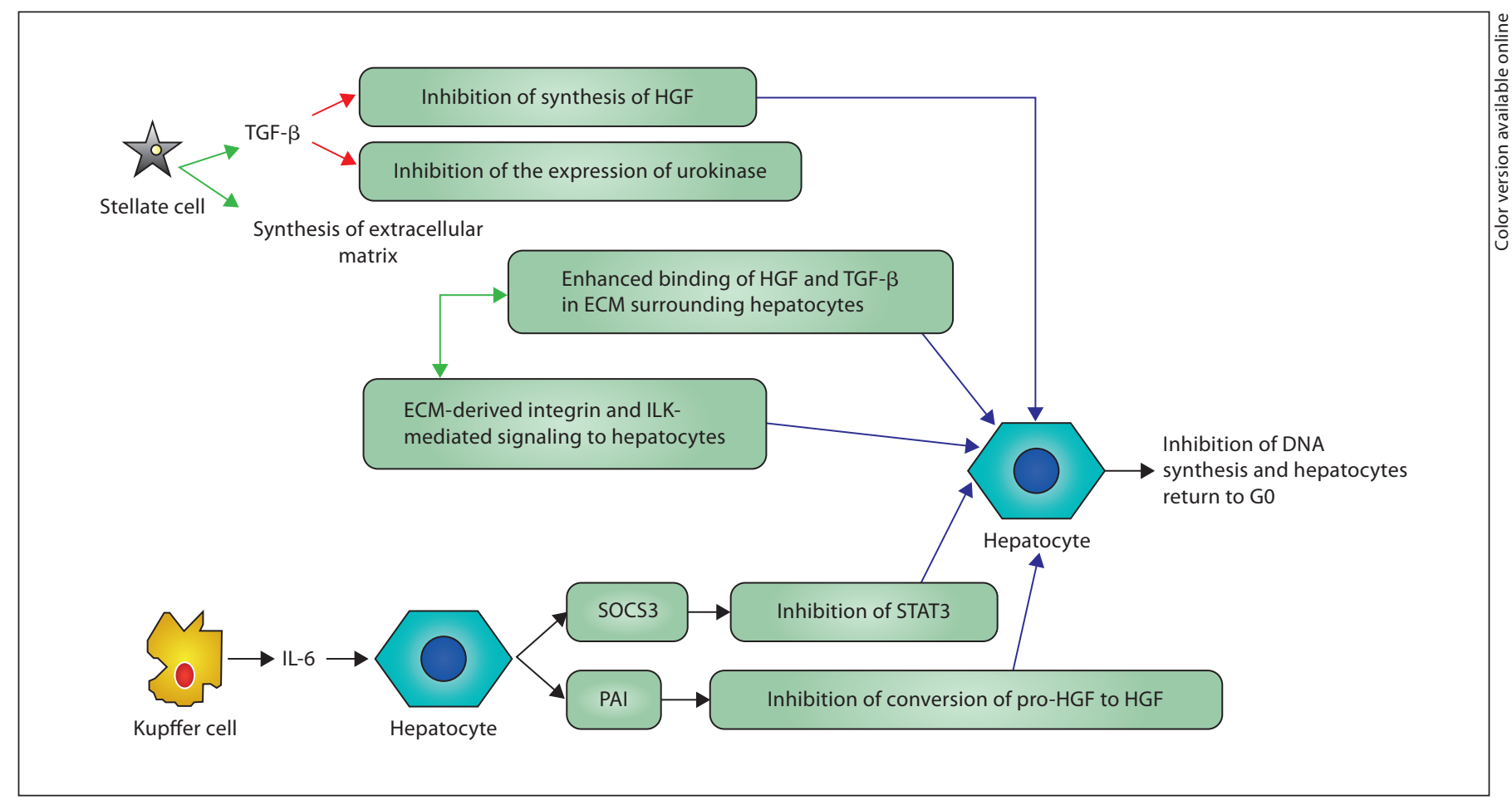

Fig. 2. Termination of regeneration is a complex process controlled by multiple factors like TGF- $\beta$, ECM, SOCS3 and IL-6. ECM = Extracellular matrix; ILK = integrin-linked kinase.

glycosaminoglycans and heparin) and preventing it from being activated by urokinase, which disappears anyway at the end of regeneration and its expression is inhibited by TGF- $\beta$. These events would bring hepatocytes back into a state of quiescence surrounded by HGF (bound to glycosaminoglycans) and TGF- $\beta$ (bound to decorin). In this scenario, early mitogenic stimuli such as HGF and EGF drive both hepatocyte proliferation and enhanced expression of TGF- $\beta$. Proliferating hepatocytes become resistant to TGF- $\beta$. However, TGF- $\beta$ stimulates the production of extracellular matrix and the formation of hepatic sinusoids, and also inhibits the expression of HGF and urokinase $[84,85]$. New extracellular matrix synthesis by stellate cells stimulated by TGF- $\beta$ restores the binding of both HGF and TGF- $\beta_{1}$ and reestablishes quiescence of hepatocytes in G0 (fig. 2) [26].

Activin is an apoptogen of the TGF- $\beta$ family that blocks hepatocyte mitogenesis. Activin shows diminished signaling during liver regeneration when its cellular receptor level is reduced, but the receptor level is restored once liver regeneration is terminated [90].

Suppressors of cytokine signaling (SOCS) are important negative regulators of cytokine signaling that pre- vent the tyrosine phosphorylation of STAT proteins. SOCS directly interact with phosphorylated JAK kinases and prevent the activation of STAT3. It has been shown that IL- 6 signaling in the liver causes the rapid upregulation of SOCS3, which correlates with the subsequent downregulation of phosphorylated STAT3, thereby terminating the IL-6 signal (fig. 2) [50].

IL-6 itself could have a role in terminating the HGF signal by inducing PAI, which blocks the processing of pro-HGF into active HGF (fig. 2) [91].

Hippo kinase signaling cascade [a growth-suppressive pathway that ultimately antagonizes the transcriptional coactivator YAP (Yes-associated protein)] can also control hepatocyte proliferation [26]. Overexpression of YAP in a transgenic mouse model leads to unchecked hepatocyte proliferation, massive liver hyperplasia and hepatic carcinogenesis, while blocking the overexpression of YAP leads to a return of the liver to its normal size. It is possible, therefore, that the Hippo kinase pathway has an important role in the termination of liver regeneration and the determination of the overall liver size [92]. 
Fig. 3. Factors affecting liver regeneration after liver transplantation.

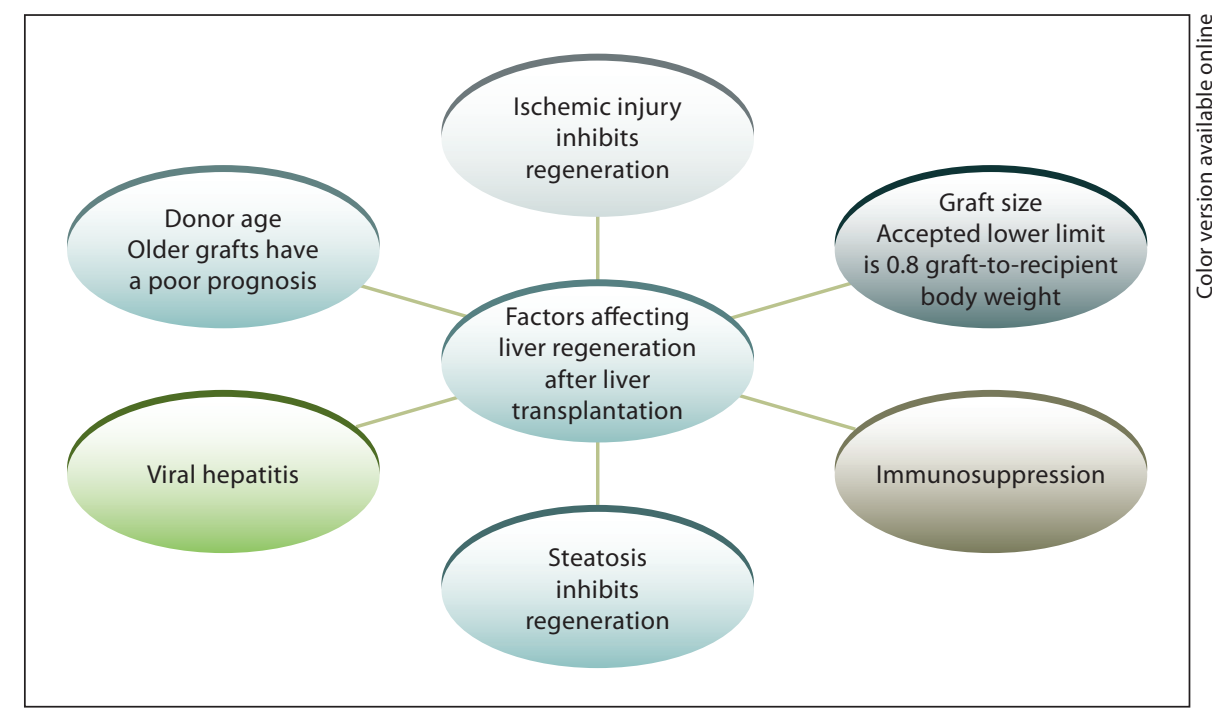

\section{Factors Affecting Liver Regeneration after Transplantation}

Regeneration is crucial in liver transplantation. In cadaveric transplantation, hepatocyte loss due to (1) ischemia-reperfusion injury, (2) damage that may have occurred in the donor and (3) alloimmune response, requires replacement [8].

Regeneration is also critically required in the setting of LDLT because even though the ischemic injury is minimized in LDLT, this technique supplies a graft, which by definition is too small, by transplanting only $50-60 \%$ of the expected liver volume in adults, which requires vigorous immediate hepatocyte proliferation in both the recipients and the donors [7].

Factors that have been shown to have a significant effect on liver regeneration in both experimental and clinical settings include ischemic injury, graft size, immunosuppression, steatosis, donor age and viral hepatitis (fig. 3).

\section{Ischemic Injury}

Animal studies have shown impaired regeneration when massive hepatectomy is combined with warm ischemic injury [93].

Ischemic injury, both warm and cold, is an unavoidable component of transplantation, although ischemic injury in LDLT is minimized by careful planning of the donor and recipient procedures. After prolonged cold ischemia of whole liver grafts, there is an initiation of the cell cycle pathways with an upregulation of the markers of liver regeneration. The more extensive the ischemic in- jury, the greater the expression and activation of cytokines, transcription factors and immediate early genes and the greater the magnitude of hepatocellular replication [8].

However, the liver can only tolerate ischemic injury up to a certain point, after which the damage is too extensive and the graft is unable to maintain functional homeostasis and regenerative capabilities, which results in liver dysfunction and graft failure [94].

Theoretically, there could be an advantage in ischemic preconditioning of the graft, as it was shown to improve liver function after liver resection [95]. However, it is apparent that when rodent partial grafts are subjected to ischemic injury of more than $10 \mathrm{~h}$, there is a significant effect on survival with extensive hepatic necrosis, inability to initiate or maintain the regenerative response, and decreased survival [96].

The clinical impact of cold ischemia has been demonstrated in a multicenter report of LDLT, where every hour of additional cold ischemia added a significant risk of graft loss [97].

\section{Graft Size}

The amount of liver mass transplanted has been shown to be an important variable after transplantation. Early experimental studies addressing regeneration after transplantation show that a small-for-size graft will adapt to its environment and achieve a size equal to the original native liver. It became apparent that the graft size-to-recipient ratio was critical, in that grafts that were too small had decreased survival [98]. 
These findings correlated with clinical experience in that small-for-size grafts regenerate to an appropriate size for the recipient. However, there was significant functional impairment of these grafts, as evidenced by cholestasis and histologic changes consistent with ischemic injury. Liver grafts with a graft weight to standard liver volume ratio of less than $40 \%$ were found to have poor graft survival and prolonged hyperbilirubinemia [99, 100].

Using animal models of partial liver graft transplantation, investigators have studied the interplay between the regenerative response and ischemic injury in the setting of 50 and $30 \%$ size grafts. The partial grafts showed a robust regenerative response if the ischemic injury was minimal. However, it became apparent that when these partial grafts were subjected to ischemic injury of moderate to prolonged time periods, there was a significant effect on survival with extensive hepatic necrosis, the inability to initiate or maintain the regenerative response, and decreased survival. This shows the diminished tolerance of small-for-size grafts for additional injury beyond transplantation itself $[96,101]$.

Although ischemic injury in LDLT is minimized, the amount of critical liver mass required for transplantation in living donation remains in question. Most centers have defined liver mass as graft-to-recipient body weight or as a percentage of the standard liver volume. Unfortunately, no uniform method of measuring or reporting graft volume in relation to the recipient has been established. Clinical experience with living donor and split grafts has led to an accepted lower limit of $0.8 \%$ graft-to-recipient body weight or $40 \%$ of the standard liver volume [21].

As seen in experimental models, the accumulation of additional stressful stimuli, such as sepsis or renal failure, may push a relatively small graft into failure. Patients with fulminant hepatic failure and those with significant metabolic stress may require more liver volume than stable patients undergoing transplantation under elective conditions [100].

Although it has been performed successfully, many centers are not performing LDLT in acutely ill patients with fulminant failure because of the uncertainty of whether a partial graft has enough volume to support the recovery of such a recipient [81].

The administration of agents that stimulate hepatocyte proliferation by either inducing their entry into the cell cycle or maintaining them as replicative cells may help to shorten the time needed for full organ growth and improve the recovery of both donor and transplant recipient after surgery [6].

Liver Regeneration after Transplantation
A variety of strategies have been developed to enhance liver regeneration after liver transplantation including the injection of growth factors like HGF [102] and hormones like $\mathrm{T}_{3}$ [103-105]. However, these strategies have only been applied to rats and whether interspecies differences (rats vs. humans) will prevent the application of these approaches on humans will require further experimentation.

\section{Immunosuppression}

The clinical implications of inhibition or enhancement of the process of liver regeneration by pharmacological means becomes evident in the setting of the transplantation of grafts with significant injury from prolonged preservation and ischemia and in partial living donor grafts [21].

Within the graft environment, the host immune response must be inhibited to avoid acute allograft rejection, and inhibition of this response may also interfere with the recovery of liver grafts requiring active regeneration of hepatocytes. Glucocorticoids, routinely used in immunosuppression protocols, have been shown to markedly inhibit cell cycle progression in both $\mathrm{PH}$ models and in transplant models with ischemic injury [106, 107]. Cyclosporine and tacrolimus may have differential effects on regeneration in a dose-dependent fashion [108, 109]. Sirolimus (rapamycin), with its antiproliferative action, interferes with hepatocyte replication [110].

Rapid hepatocyte replication and smaller liver mass also may interfere with the metabolism and pharmacokinetics of certain drugs. Preliminary studies have shown that LDLT recipients require lower doses of tacrolimus in the early postoperative period than patients receiving whole grafts [111].

\section{Steatosis}

In the prereplicative phase of rodent liver regeneration after $\mathrm{PH}$, fatty infiltration of the remnant lobes occurs. Although this phenomenon has been observed for decades, it has received renewed interest lately, as hepatic steatosis is becoming a more prevalent human disease [81].

Steatosis (fatty liver change) occurs with a number of disease processes including diabetes, acute fatty liver of pregnancy and morbid obesity. It also occurs after acute alcohol ingestion or with the use of several medications (e.g. tetracycline, fluconazole and nifedipine) [25].

Hepatic steatosis affects regeneration on several molecular levels. Steatotic livers in rats show delayed mitosis and increased mortality after $\mathrm{PH}$, which may be due to 
abnormal TNF and IL-6 signaling [112]. The coordinated induction of JNKs and ERKs is disrupted after PH in fat livers of ob/ob mice (a model for steatohepatitis) with enhanced ATK and inhibition of PEPCK. Cyclin D1 induction is abolished along with STAT3 and reduced ATP levels, which may arrest cell cycle progression [113].

Lipid accumulation has been associated with hepatocyte mitochondrial damage caused by free radical injury from fatty acid oxidation. Abnormalities in the induction of cytochrome P-450 may be one mechanism in the pathophysiology of these findings in fatty livers and may contribute to poor regeneration $[114,115]$.

Numerous animal studies have shown a marked impairment of regeneration in steatotic livers, as well as the inability to tolerate warm ischemic injury [112]. These findings correlate with the decreased survival of patients with steatotic livers following resection [116] and in clinical transplantation setting, as liver grafts with severe steatosis $(>60 \%)$ have higher rates of primary nonfunction, higher transaminases and poorer graft survival, possibly as a result of the inability to initiate repair and regeneration mechanisms $[117,118]$.

Although deceased donor grafts with severe macrovesicular steatosis should therefore not be used, those with less than 30\% macro- or microvesicular steatosis can be transplanted with immediate and long-term results similar to those of organs without fat [119]. Marcos et al. [120] showed that the function of right-lobe living donor grafts with up to $30 \%$ steatosis did not differ from fat-free grafts, and regeneration seemed not to be impaired, but many living donor programs will not use grafts with greater than $10-20 \%$ steatosis, and some centers will not accept any steatosis in living donor grafts [81].

Because donor steatosis affects both susceptibility to ischemic injury and regenerative capacity, some groups have empirically suggested increasing the necessary liver mass by $1 \%$ standard liver volume for each percentage of steatosis [7].

Steatohepatitis (inflammation of the liver in the setting of fatty infiltration) carries an even greater risk and should be considered as a contraindication for donation. In those livers, lipid accumulation is associated with hepatocyte mitochondrial damage and abnormalities in cytochrome $\mathrm{P} 450$ induction. This is caused by free radical injury from abnormal fatty acid oxidation and the accumulation of dicarboxylic fatty acids during intermediary metabolism. Both donors and recipients would be at risk from liver failure and hepatocyte apoptosis in this setting [81].
However, experimental data have shown that normal fat metabolism plays an important role in the regenerative phase after liver resection and helps rather than hinders regeneration. Peroxisome proliferator-activated receptor- $\alpha$ (PPAR- $\alpha$ ), which regulates hepatic lipid turnover in rodents, appears to be necessary for normal liver regeneration. Mice in which the normal accumulation of fat was prevented had a profound deficit in hepatocyte proliferation, suggesting that fat accumulation may serve as a fuelling source for the energy needed by the regeneration process $[121,122]$.

\section{Donor Age}

Liver age is a significant factor in hepatocellular regeneration. Older livers do not regenerate as quickly as younger ones and show delayed regeneration after acute injury. Rodent models have shown a reduced and delayed DNA synthesizing capacity [123], and a clinical study showed a greater graft/standard liver volume in the young donor livers compared with middle-aged and older donor grafts. The older livers also had a higher prothrombin time in the early postoperative period [124].

The graft survival of older living donor grafts is inferior to younger grafts, and whether this is because of a decreased ability to regenerate alongside the other stresses of transplantation is yet to be shown [125].

In the transplantation setting, older grafts have poorer long-term survival when combined with longer cold ischemic times [7].

It must be emphasized that age may affect the regeneration and recovery of the living donor as well as the recipient. Many liver programs limit the upper age limit of the donor, and although no definite age has been specified, 55-60 years old is a generally accepted upper age limit [81].

\section{Viral Hepatitis}

The processes of viral replication, alloimmune response, metabolic function and cancer recurrence have all been correlated with cellular replication [81].

Because the majority of liver transplant patients have hepatitis $\mathrm{C}$, it is important to know if this vigorous regenerative response in the partial graft has a significant effect on the kinetics of viral replication in hepatitis $C$ virus (HCV)-positive individuals. Early results suggest that recipients of living-donor liver transplants may have an earlier and more severe recurrence of HCV compared with recipients of whole cadaveric liver grafts [126, 127]. However, this has not been confirmed in other studies [128-130]. 
Because the primary target cell for HCV replication in vivo is the hepatocyte, events that lead to hepatocyte proliferation may enhance HCV replication [131].

Investigators have noted that HCV RNA replication is enhanced in proliferating cells, suggesting that viral replication is regulated by cell cycle-dependent factors [132, 133].

\section{Other Factors}

There is clinical and experimental evidence that several other factors may influence the regenerative response after transplantation.

Increased portal venous flow has been implicated in a more rapid regeneration. However, increased portal pressure, as encountered in small-for-size grafts when the full portal vein flow has to traverse through a much-reduced liver size, the pressure building up in the portal vein effectively shuts down the flow through the portal arterioles and the liver becomes dearterialized leading to graft failure [134].

Poor hepatic venous drainage has been shown to inhibit regeneration and segments with poor venous drainage become atrophied with time. Female gender may have a positive effect on the regeneration of partial grafts in murine models, but no human study has confirmed this finding [81].

\section{Donor Liver Regeneration}

With the recent advent of cadaveric split and LDLT, the opportunity has arisen to study liver regeneration in humans more closely [135].

The most common question asked by potential donors is, 'When will my liver grow back and will it have normal function?'

Several reports have shown that the remnant liver of the donor grows more slowly than the transplanted portion and may not regenerate to the full volume that it had before the operation, and that ultimately it reaches approximately only $85-90 \%$ of the mass of the donor's original liver even after 1 year [135-138]. This is contrary to what was previously believed and different from rodent models [7]. However, most of the donors achieved normal liver synthetic function within 1 postoperative week and without complications [137, 138].

Rapid recipient liver regeneration may be related to high liver blood flow after LDLT because of the persistence of a hyperdynamic state, immunosuppressant administration (cyclosporine and tacrolimus stimulate liver regeneration) or humoral factors in the recipient (HGF, IL- 6 and TNF- $\alpha$ ) [138].

Due to the fact that liver function is completely restored in the donor by 1 month after transplantation, it is possible that there is a lack of growth stimulatory signals as additional mass is not required to sustain normal hepatic function. On the other hand, it is likely that although it is capable of functioning adequately under normal conditions, the incompletely regenerated donor liver may have a deficit in its reserve capacity [135].

\section{Conclusions}

Liver transplantation has opened an exciting opportunity to study liver regeneration in humans. Several factors affect liver regeneration after transplantation such as ischemic injury, graft size, immunosuppression, steatosis, donor age and viral hepatitis. A combination of radiological imaging, liver biopsies and plasma measurements could provide significant data which would lead to a better understanding of the factors and pathways that control liver regeneration after liver transplantation; this in turn could be used to enhance liver regeneration after transplantation and to solve clinical problems such as liver failure in cases of small-for-size grafts.

\section{Acknowledgements}

This study was supported by the China National S\&T Major Project (No. 2012ZX10002017) and by the Team Program of Science and Technology Bureau of Zhejiang Province (No. 2009R50038).

\section{Disclosure Statement}

The authors declare no conflict of interest.

\begin{tabular}{|c|c|c|}
\hline References & $\begin{array}{l}>_{2} \\
>3\end{array}$ & $\begin{array}{l}\text { Saxema R, Zucker SD, Crawford JM: Anato- } \\
\text { my and physiology of the liver; in Zakim DZ, } \\
\text { Boyer TD (eds): Hepatology: A Textbook of } \\
\text { Liver Disease, ed 4. Philadelphia, Saunders, } \\
\text { 2003, pp 3-30. } \\
\text { Taub R: Liver regeneration: from myth to } \\
\text { mechanism. Nat Rev Mol Cell Biol 2004;5: } \\
\text { 836-847. } \\
\text { Minuk GY: Hepatic regeneration: if it ain't } \\
\text { broke, don't fix it. Can J Gastroenterol 2003; } \\
\text { 17:418-424. }\end{array}$ \\
\hline
\end{tabular}


4 Higgins GM, Anderson RM: Experimental pathology of the liver: restoration of the liver of the white rat following partial surgical removal. Arch Pathol 1931;12:186-202.

5 Moser MJ, Gong Y, Zhang MN, Johnston J, Lipschitz J, Minuk GY: Immediate-early protooncogene expression and liver function following various extents of partial hepatectomy in the rat. Dig Dis Sci 2001;46:907-914.

6 Fausto N: Liver regeneration: from laboratory to clinic. Liver Transpl 2001;7:835-844.

$\checkmark 7$ Olthoff KM: Hepatic regeneration in living donor liver transplantation. Liver Transpl 2003;9:S35-S41.

-8 Debonera F, Aldeguer X, Shen X, Gelman AE, Gao F, Que X, Greenbaum LE, Furth EE, Taub R, Olthoff KM: Activation of interleukin-6/STAT3 and liver regeneration after transplantation. J Surg Res 2001;96:289-295.

-9 Michalopoulos GK, DeFrances MC: Liver regeneration. Science 1997;276:60-66.

-10 Sandgren EP, Palmiter RD, Heckel JL, Daugherty CC, Brinster RL, Degen JL: Complete hepatic regeneration after somatic deletion of an albumin-plasminogen activator transgene. Cell 1991;66:245-256.

- 11 Overturf K, Al-Dhalimy M, Tanguay R, Brantly M, Ou CN, Finegold M, Grompe M: Hepatocytes corrected by gene therapy are selected in vivo in a murine model of hereditary tyrosinaemia type I. Nat Genet 1996;12: 266-273.

12 Fausto N, Campbell JS: The role of hepatocytes and oval cells in liver regeneration and repopulation. Mech Dev 2003;120:117-130.

13 Chattopadhyay P, Wahi AK, Agrawal SS: Organogenesis and regeneration of liver: mechanism and signal cascade. Asian J Biochem 2007;2:364-374.

14 Grisham JW: A morphologic study of deoxyribonucleic acid synthesis and cell proliferation in regenerating rat liver: autoradiography with thymidine-H. Cancer Res 1962;22: 842-849.

15 Bucher NLR: Regeneration of mammalian liver. Int Rev Cytol 1963;15:245-300.

16 Sell S: Heterogeneity and plasticity of hepatocyte lineage cells. Hepatology 2001;33: $738-750$.

-17 Shafritz DA, Dabeva MD: Liver stem cells and model systems for liver repopulation. J Hepatol 2002;36:552-564.

18 Kandilis AN, Koskinas J, Tiniakos DG, Nikiteas N, Perrea DN: Liver regeneration: focus on cell types and topographic differences. Eur Surg Res 2010;44:1-12.

19 Vassilopoulos G, Wang PR, Russell DW: Transplanted bone marrow regenerates liver by cell fusion. Nature 2003;922:901-904.

20 Duncan AW, Dorrell C, Grompe M: Stem cells and liver regeneration. Gastroenterology 2009; $137: 466-481$.

21 Olthoff KM: Liver regeneration: clinical relevance; in Blumgart LH (ed): Surgery of the Liver, Biliary Tract and Pancreas, ed 4. Philadelphia, Saunders, 2007, pp 54-62.
22 Chattopadhyay P, Agrawal SS, Garg A: Triiodothyronine $\left(\mathrm{T}_{3}\right)$ regulation of liver cell regeneration in alcohol-induced liver cell injury in partially hepatoctomised albino rats. Ind J Gastroentrol 2006;25:165-166.

23 Chattopadhyay P, Garg A, Varshney VP, Shama AK, Agarawal SS: Increase insulin activity by Phyllanthus amarus Linn on liver regeneration in partially hepatoctomised albino rats. Res J Med Plant 2007;1:17-20.

24 Taub R: Hepatic regeneration; in Zakim DZ, Boyer TD (eds): Hepatology: A Textbook of Liver Disease, ed 4. Philadelphia, Saunders, 2003, pp 31-48.

25 Koniaris LG, McKillop IH, Schwartz SI, Zimmers TA: Liver regeneration. J Am Coll Surg 2003;197:634-359.

26 Michalopoulos GK: Liver regeneration. J Cell Physiol 2007;213:286-300.

27 Webber EM, Bruix J, Pierce RH, Fausto N: Tumor necrosis factor primes hepatocytes for DNA replication in the rat. Hepatology 1998;28:1226-1234.

28 Akerman P, Cote P, Yang SQ, McClain C, Nelson S, Bagby GJ, Diehl AM: Antibodies to tumor necrosis factor-alpha inhibit liver regeneration after partial hepatectomy. Am J Physiol 1992;263:G579-G585.

29 Trautwein C, Rakemann T, Niehof M, RoseJohn S, Manns MP: Acute-phase response factor, increased binding, and target gene transcription during liver regeneration. Gastroenterology 1996;110:1854-1862.

30 Iwai M, Cui TX, Kitamura H, Saito M, Shimazu T: Increased secretion of tumour necrosis factor and interleukin 6 from isolated, perfused liver of rats after partial hepatectomy. Cytokine 2001;13:60-64.

- 31 Cressman DE, Greenbaum LE, DeAngelis RA, Ciliberto G, Furth EE, Poli V, Taub R: Liver failure and defective hepatocyte regeneration in interleukin-6-deficient mice. Science 1996;274:1379-1383.

-32 Yamada Y, Kirillova I, Peschon JJ, Fausto N: Initiation of liver growth by tumor necrosis factor: deficient liver regeneration in mice lacking type I tumor necrosis factor receptor. Proc Natl Acad Sci USA 1997;94:1441-1446.

33 Beg AA: Endogenous ligands of Toll-like receptors: implications for regulating inflammatory and immune responses. Trends Immunol 2002;23:509-512.

34 Cornell RP, Lilijequist BL, Bartizal KF: Depressed liver regeneration after partial hepatectomy in germ-free athymic and lipopolysaccharide-resistant mice. Hepatology 1990; 11:916-922.

- 35 Strey CW, Markiewski M, Mastellos D, Tudoran R, Spruce LA, Greenbaum LE, Lambris JD: The proinflammatory mediators $\mathrm{C} 3 \mathrm{a}$ and $\mathrm{C} 5 \mathrm{a}$ are essential for liver regeneration. J Exp Med 2003;198:913-923.
36 LaMarre J, Hayes MA, Wollenberg GK, Hussaini I, Hall SW, Gonias SL: An alpha 2-macroglobulin receptor-dependent mechanism for the plasma clearance of transforming growth factor-beta 1 in mice. J Clin Invest 1991;87:39-44

37 Monga SP, Pediaditakis P, Mule K, Stolz DB, Michalopoulos GK: Changes in WNT/betacatenin pathway during regulated growth in rat liver regeneration. Hepatology 2001;33: 1098-1109.

38 Kohler C, Bell AW, Bowen WC, Monga SP, Fleig W, Michalopoulos GK: Expression of Notch-1 and its ligand Jagged-1 in rat liver during liver regeneration. Hepatology 2004; 39:1056-1065.

39 Taub R, Greenbaum L, Peng Y: Transcriptional regulatory signals define cytokine dependent and independent pathways in liver regeneration. Semin Liver Dis 1999;19:117127.

40 Sakamoto T, Liu Z, Murase N, Ezure T, Yokomuro S, Poli V, Demetris AJ: Mitosis and apoptosis in the liver of interleukin-6-deficient mice after partial hepatectomy. Hepatology 1999;29:403-411.

- 41 Aldeguer X, Debonera F, Shaked A, Krasinkas AM, Gelman AE, Que X, Zamir GA, Hiroyasu S, Kovalovich KK, Taub R, Olthoff KM: Interleukin- 6 from intrahepatic cells of bone marrow origin is required for normal murine liver regeneration. Hepatology 2002;35:40-48.

42 Wuestefeld T, Klein C, Streetz KL, Betz U, Lauber J, Buer J, Manns MP, Müller W, Trautwein C: Interleukin-6/glycoprotein 130 -dependent pathways are protective during liver regeneration. J Biol Chem 2003;278: 11281-11288.

43 Cressman DE, Diamond RH, Taub R: Rapid activation of the Stat 3 transcription complex in liver regeneration. Hepatology 1995;21: 1443-1449.

44 FitzGerald MJ, Webber EM, Donovan JR, Fausto N: Rapid DNA binding by nuclear factor kappa B in hepatocytes at the start of liver regeneration. Cell Growth Differ 1995; 6:417-427.

45 DeAngelis RA, Kovalovich K, Cressman DE, Taub R: Normal liver regeneration in p50/ nuclear factor kappaB1 knockout mice. Hepatology 2001;33:915-924.

-46 Li W, Liang X, Kellendonk C, Poli V, Taub R: STAT3 contributes to the mitogenic response of hepatocytes during liver regeneration. J Biol Chem 2002;277:28411-28417.

47 Hayashi $\mathrm{H}$, Nagaki M, Imose M, Osawa Y, Kimura K, Takai S, Imao M, Naiki T, Kato T, Moriwaki H: Normal liver regeneration and liver cell apoptosis after partial hepatectomy in tumor necrosis factor-alpha-deficient mice. Liver Int 2005;25:162-170.

-48 Fujita J, Marino MW, Wada H, Jungbluth AA, Mackrell PJ, Rivadeneira DE, Stapleton PP, Daly JM: Effect of TNF gene depletion on liver regeneration after partial hepatectomy in mice. Surgery 2001;129:48-54. 
49 Fausto N, Campbell JS, Riehle KJ: Liver regeneration. Hepatology 2006;43:S45-S53.

-50 Campbell JS, Prichard L, Schaper F, Schmitz J, Stephenson-Famy A, Rosenfeld ME, Argast GM, Heinrich PC, Fausto N: Expression of suppressors of cytokine signaling during liver regeneration. J Clin Invest 2001;107: 1285-1292.

-51 Pediaditakis P, Lopez-Talavera JC, Petersen B, Monga SP, Michalopoulos GK: The processing and utilization of hepatocyte growth factor/scatter factor following partial hepatectomy in the rat. Hepatology 2001;34:688693.

52 Currier AR, Sabla G, Locaputo S, et al: Plasminogen directs the pleiotropic effects of uPA in liver injury and repair. Am J Physiol Gastrointest Liver Physiol 2003;284:G508G515.

53 Okano J, Shiota G, Matsumoto K, Yasui S, Kurimasa A, Hisatome I, Steinberg P, Murawaki Y: Hepatocyte growth factor exerts a proliferative effect on oval cells through the PI3K/AKT signaling pathway. Biochem Biophys Res Commun 2003;309:298-304.

54 Borowiak M, Garratt AN, Wustefeld T, Strehle M, Trautwein C, Birchmeier C: Met provides essential signals for liver regeneration. Proc Natl Acad Sci USA 2004;101:1060810613.

-55 Naldini L, Vigna E, Narsimhan RP, Gaudino G, Zarnegar R, Michalopoulos GK, Comoglio PM: Hepatocyte growth factor (HGF) stimulates the tyrosine kinase activity of the receptor encoded by the proto-oncogene cMET. Oncogene 1991;6:501-504.

56 Burr A, Toole K, Chapman C, Hines JE, Burt AD: Anti-hepatocyte growth factor antibody inhibits hepatocyte proliferation during liver regeneration. J Pathol 1998;185:298-302.

-57 Huh CG, Factor VM, Sánchez A, Uchida K, Conner EA, Thorgeirsson SS: Hepatocyte growth factor/c-met signaling pathway is required for efficient liver regeneration and repair. Proc Natl Acad Sci USA 2004; 101:44774482.

58 Schmidt C, Bladt F, Goedecke S, Brinkmann V, Zschiesche W, Sharpe M, Gherardi E, Birchmeier C: Scatter factor/hepatocyte growth factor is essential for liver development. Nature 1995;373:699-702.

-59 Dietrich S, Abou-Rebyeh F, Brohmann H, Bladt F, Sonnenberg-Riethmacher E, Yamaai T, Lumsden A, Brand-Saberi B, Birchmeier C: The role of SF/HGF and c-Met in the development of skeletal muscle. Development 1999;126:1621-1629.

60 Bucher NL, Patel U, Cohen S: Hormonal factors concerned with liver regeneration. Ciba Found Symp 1977;55:95-107.

-61 Skov Olsen P, Boesby S, Kirkegaard P, Therkelsen K, Almdal T, Poulsen SS, Nexo E: Influence of epidermal growth factor on liver regeneration after partial hepatectomy in rats. Hepatology 1988;8:992-996.
62 Olsen PS, Poulsen SS, Kirkegaard P: Adrenergic effects on secretion of epidermal growth factor from Brunner's glands. Gut 1985;26:920-927.

63 Cruise JL, Houck KA, Michalopoulos GK: Induction of DNA synthesis in cultured rat hepatocytes through stimulation of alpha 1 adrenoreceptor by norepinephrine. Science 1985;227:749-751.

64 Houck KA, Cruise JL, Michalopoulos G: Norepinephrine modulates the growth inhibitory effect of transforming growth factor-beta in primary rat hepatocyte cultures. J Cell Physiol 1988;135:551-555.

65 Mead JE, Fausto N: Transforming growth factor alpha may be a physiological regulator of liver regeneration by means of an autocrine mechanism. Proc Natl Acad Sci USA 1989;86:1558-1562.

66 Webber EM, Wu JC, Wang L, Merlino G, Fausto N: Overexpression of transforming growth factor-alpha causes liver enlargement and increased hepatocyte proliferation in transgenic mice. Am J Pathol 1994;145: 398-408.

67 Russell WE, Kaufmann WK, Sitaric S, Leutteke NC, Lee DC: Liver regeneration and hepatocarcinogenesis in transforming growth factor alpha-targeted mice. Mol Carcinog 1996;15:183-189.

68 Kiso S, Kawata S, Tamura S, Inui Y, Yoshida Y, Sawai Y, Umeki S, Ito N, Yamada A, Miyagawa J, Higashiyama S, Iwawaki T, Saito M, Taniguchi N, Matsuzawa Y, Kohno K: Liver regeneration in heparin-binding EGF-like growth factor transgenic mice after partial hepatectomy. Gastroenterology 2003; 124: 701-707.

69 Mitchell C, Nivison M, Jackson LF, Fox R, Lee DC, Campbell JS, Fausto N: Heparinbinding epidermal growth factor-like growth factor links hepatocyte priming with cell cycle progression during liver regeneration. J Biol Chem 2005;280:2562-2568.

70 Berasain C, Garcia-Trevijano ER, Castillo J, Erroba E, Lee DC, Prieto J, Avila MA: Amphiregulin: an early trigger of liver regeneration in mice. Gastroenterology 2005; 128: 424-432.

71 LeCouter J, Moritz DR, Li B, Phillips GL, Liang XH, Gerber HP, Hillan KJ, Ferrara N: Angiogenesis-independent endothelial protection of liver: role of VEGFR-1. Science 2003;299:890-893.

-72 Schwabe RF, Bradham CA, Uehara T, Hatano E, Bennett BL, Schoonhoven R, Brenner DA: c-Jun-N-terminal kinase drives cyclin D1 expression and proliferation during liver regeneration. Hepatology 2003;37:824-832.

73 Talarmin H, Rescan C, Cariou S, Glaise D, Zanninelli G, Bilodeau M, Loyer P, GuguenGuillouzo C, Baffet G: The mitogen-activated protein kinase/extracellular signal-regulated kinase cascade activation is a key signalling pathway involved in the regulation of G1 phase progression in proliferating hepatocytes. Mol Cell Biol 1999;19:6003-6011.
74 Behrens A, Sibilia M, David JP, Möhle-Steinlein U, Tronche F, Schütz G, Wagner EF: Impaired postnatal hepatocyte proliferation and liver regeneration in mice lacking $\mathrm{c}$-jun in the liver. EMBO J 2002;21:1782-1790.

75 Peters M, Blinn G, Jostock T, Schirmacher P, Meyer zum Büschenfelde KH, Galle PR, Rose-John S: Combined interleukin 6 and soluble interleukin 6 receptor accelerates murine liver regeneration. Gastroenterology 2000;119:1663-1671.

76 Leu JI, Crissey MAS, Leu JP, Ciliberto G, Taub R: Interleukin-6-induced Stat3 and AP-1 amplify hepatocyte nuclear factor 1-mediated transactivation of hepatic genes, an adaptive response to liver injury. Mol Cell Biol 2001;21:414-424.

-77 Weir E, Chen Q, Defrances MC, Bell A, Taub $\mathrm{R}$, Zarnegar R: Rapid induction of mRNAs for liver regeneration factor (LRF-1) and insulin-like growth factor binding protein-1 (IGFBP-1) in primary cultures of rat hepatocytes by hepatocyte growth factor and epidermal growth factor. Hepatology 1994;20: 955-960.

78 Kim TH, Mars WM, Stolz DB, Michalopoulos GK: Expression and activation of proMMP-2 and pro-MMP-9 during rat liver regeneration. Hepatology 2000;31:75-82.

79 Argast GM, Campbell JS, Brooling JT, Fausto $\mathrm{N}$ : Epidermal growth factor receptor transactivation mediates tumor necrosis factorinduced hepatocyte replication. J Biol Chem 2004;279:34530-34536.

80 Lee DC, Sunnarborg SW, Hinkle CL, Myers TJ, Stevenson MY, Russell WE, Castner BJ, Gerhart MJ, Paxton RJ, Black RA, Chang A, Jackson LF: TACE/ADAM17 processing of EGFR ligands indicates a role as a physiological convertase. Ann NY Acad Sci 2003;995: 22-38.

81 Jonge J, Olthoff KM: Liver regeneration; in Gruessner RWG, Benedetti E (eds): Living Donor Organ Transplantation, ed 1. New York, McGraw-Hill, 2008, pp 459-467.

82 Derynck R, Zhang YE: Smad-dependent and Smad-independent pathways in TGF-beta family signalling. Nature 2003;425:577584.

83 Houck KA, Michalopoulos GK: Altered responses of regenerating hepatocytes to norepinephrine and transforming growth factor type beta. J Cell Physiol 1989;141:503509.

84 Gohda E, Matsunaga T, Kataoka H, Yamamoto I: TGF-beta is a potent inhibitor of hepatocyte growth factor secretion by human fibroblasts. Cell Biol Int Rep 1992;16:917926.

85 Mars WM, Kim TH, Stolz DB, Liu ML, Michalopoulos GK: Presence of urokinase in serum-free primary rat hepatocyte cultures and its role in activating hepatocyte growth factor. Cancer Res 1996;56:2837-2843. 
-86 Rana B, Mischoulon D, Xie Y, Bucher NL, Farmer SR: Cell-extracellular matrix interactions can regulate the switch between growth and differentiation in rat hepatocytes: reciprocal expression of C/EBP alpha and immediate-early growth response transcription factors. Mol Cell Biol 1994;14: 5858-5869.

87 Gkretsi V, Bowen WC, Yang Y, Wu C, Michalopoulos GK: Integrin-linked kinase is involved in matrix-induced hepatocyte differentiation. Biochem Biophys Res Commun 2007;353:638-643.

88 Gkretsi V, Apte U, Mars WM, Bowen WC, Luo JH, Yang Y, Yu YP, Orr A, St-Arnaud R, Dedhar S, Kaestner KH, Wu C, Michalopoulos GK: Liver-specific ablation of integrinlinked kinase in mice results in abnormal histology, enhanced cell proliferation, and hepatomegaly. Hepatology 2008;48:19321941.

-89 Apte U, Gkretsi V, Bowen WC, Mars WM, Luo JH, Donthamsetty S, Orr A, Monga SP, Wu C, Michalopoulos GK: Enhanced liver regeneration following changes induced by hepatocyte-specific genetic ablation of integrin-linked kinase. Hepatology 2009;50: 844-851.

-90 Date M, Matsuzaki K, Matsushita M, Tahashi Y, Sakitani K, Inoue K: Differential regulation of activin A for hepatocyte growth and fibronectin synthesis in rat liver injury. J Hepatol 2000;32:251-260.

-91 Shimizu M, Hara A, Okuno M, Matsuno H, Okada K, Ueshima S, Matsuo O, Niwa M, Akita K, Yamada Y, Yoshimi N, Uematsu T, Kojima S, Friedman SL, Moriwaki H, Mori $\mathrm{H}$ : Mechanism of retarded liver regeneration in plasminogen activator-deficient mice: impaired activation of hepatocyte growth factor after Fas-mediated massive hepatic apoptosis. Hepatology 2001;33:569-576.

\$2 Dong J, Feldmann G, Huang J, Wu S, Zhang N, Comerford SA, Gayyed MF, Anders RA, Maitra A, Pan D: Elucidation of a universal size-control mechanism in Drosophila and mammals. Cell 2007;130:1120-1133.

$\checkmark 93$ Selzner M, Camargo CA, Clavien PA: Ischemia impairs liver regeneration after major tissue loss in rodents: protective effects of interleukin-6. Hepatology 1999;30:469-475.

94 Olthoff KM: Molecular pathways of regeneration and repair after liver transplantation. World J Surg 2002;26:831-837.

-95 Clavien PA, Selzner M, Rudiger HA, Graf R, Kadry Z, Rousson V, Jochum W: A prospective randomized study in 100 consecutive patients undergoing major liver resection with versus without ischemic preconditioning. Ann Surg 2003;238:843-852.

96 Debonera F, Que X, Aldeguer X, Abt P, Gelman AE, Shaked A, Olthoff KM: Partial liver grafts with prolonged cold preservation initiate blunted regenerative responses (abstract). Am J Transplant 2002;2:156.
$\$ 97$ Olthoff KM, Merion RM, Ghobrial RM, Abecassis MM, Fair JH, Fisher RA, Freise CE, Kam I, Pruett TL, Everhart JE, HulbertShearon TE, Gillespie BW, Emond JC: Outcomes of 385 adult-to-adult living donor liver transplant recipients: a report from the A2ALL Consortium. Ann Surg 2005;242: 314-325.

98 Francavilla A, Zeng Q, Polimeno L: Smallfor-size liver transplanted into larger recipient: a model of hepatic regeneration. Hepatology 1994;19:210-216.

-99 Kiuchi T, Kashahara M, Uryuhara K, Inomata $\mathrm{Y}$, Uemoto S, Asonuma K, Egawa $\mathrm{H}$, Fujita S, Hayashi M, Tanaka K: Impact of graft size mismatching on graft prognosis in liver transplantation from living donor. Transplantation 1999;67:321-327.

100 Lo CM, Fan ST, Liu CL, Chan JK, Lam BK, Lau GK, Wei WI, Wong J: Minimum graft size for successful living donor liver transplantation. Transplantation 1999;68:11121116.

101 Selzner N, Selzner M, Tian Y, Kadry Z, Clavien PA: Cold ischemia decreases liver regeneration after partial liver transplantation in the rat: a TNF- $\alpha /$ IL- 6 -dependent mechanism. Hepatology 2002;36:812-818.

102 Uchiyama H, Yanaga K, Nishizaki T, Soejima Y, Yoshizumi T, Sugimachi K: Effects of deletion variant of hepatocyte growth factor on reduced-size liver transplantation in rats. Transplantation 1999;68:39-44.

103 Malik R, Habib M, Tootle R, Hodgson H: Exogenous thyroid hormone induces liver enlargement, whilst maintaining regenerative potential - a study relevant to donor preconditioning. Am J Transplant 2005;5: 1801-1807.

104 Columbano A, Simbula M, Pibiri M, Perra A, Deidda M, Locker J, Pisanu A, Uccheddu A, Ledda-Columbano GM: Triiodothyronine stimulates hepatocyte proliferation in two models of impaired liver regeneration. Cell Prolif 2008;41:521-531.

105 Taki-Eldin A, Zhou L, Xie HY, Chen KJ, Zhou WH, Zhang W, Xing CY, Yang Z, Zhang K, Zheng SS: Tri-iodothyronine enhances liver regeneration after living donor liver transplantation in rats. J Hepatobiliary Pancreat Sci 2011;18:806-814.

106 Tamasi V, Kiss A, Dobozy O, Falus A, Vereczkey L, Monostory K: The effect of dexamethasone on $\mathrm{p} 450$ activities in regenerating rat liver. Biochem Biophys Res Commun 2001;286:239-242.

107 Debonera F, Krasinkas A, Gelman A, Aldeguer X, Que X, Shaked A, Olthoff KM: Dexamethasone inhibits early regenerative response of rat liver after cold preservation and transplantation. Hepatology 2003;38: 1563-1572.

108 Mazzaferro V, Porter KA, Scotti-Foglieni CL, Venkataramanan R, Makowka L, Rossaro L, Francavilla A, Todo S, Van Thiel DH, Starzl TE: The hepatotropic influence of cyclosporine. Surgery 1990;107:533-539.
09 Starzl TE, Porter KA, Mazzaferro V, Todo S, Fung J, Francavilla A: Hepatotrophic effects of FK506 in dogs. Transplantation 1991;51:67-69.

110 Francavilla A, Carr BI, Starzl TE, Azzarone A, Carrieri G, Zeng QH: Effects of rapamycin on cultured hepatocyte proliferation and gene expression. Hepatology 1992;15: 871-877.

111 Trotter JF, Stolpman N, Wachs M, Bak T, Kugelmas M, Kam I, Everson GT: Living donor liver transplant recipients achieve relatively higher immunosuppressant blood levels than cadaveric recipients. Liver Transpl 2002;8:212-218.

112 Selzner M, Clavien PA: Failure of regeneration of the steatotic rat liver: disruption at two different levels in the regeneration pathway. Hepatology 2000;31:35-42.

113 Yang SQ, Lin HZ, Mandal AK, Huang J, Diehl AM: Disrupted signaling and inhibited regeneration in obese mice with fatty livers: implications for nonalcoholic fatty liver disease patho-physiology. Hepatology 2001;34:694-706.

114 Farrel GC: Drugs and steatohepatitis. Semin Liver Dis 2002;22:185-194.

115 Kurumiya Y, Nozawa K, Sakaguchi K, Nagino M, Nimura Y, Yoshida S: Differential suppression of liver-specific genes in regenerating rat liver induced by extended hepatectomy. J Hepatol 2000;32:636-644.

116 Behrns KE, Tsiotos GG, DeSouza NE, Krishna MK, Ludwig J, Nagorney DM: Hepatic steatosis as a potential risk factor for major hepatic resection. J Gastrointest Surg 1998;2:292-298.

117 Selzner M, Clavien PA: Fatty liver in liver transplantation and surgery. Semin Liver Dis 2001;21:105-113.

118 Verran D, Kusyk T, Painter D, Fisher J, Koorey D, Strasser S, Stewart G, McCaughan G: Clinical experience gained from the use of 120 steatotic donor livers for or thotopic liver transplantation. Liver Transpl 2003;9: 500-505.

119 Urena MA, Moreno Gonzalez E, Romero CJ, Ruiz-Delgado FC, Moreno Sanz C: An approach to the rational use of steatotic donor livers in liver transplantation. Hepatogastroenterology 1999;46:1164-1173.

120 Marcos A, Fisher RA, Ham JM, Shiffman ML, Sanyal AJ, Luketic VA, Sterling RK, Fulcher AS, Posner MP: Liver regeneration and function in donor and recipient after right lobe adult to adult living donor liver transplantation. Transplantation 2000;69: 1375-1379.

121 Shteyer E, Liao Y, Muglia LJ, Hruz PW, Rudnick DA: Disruption of hepatic adipogenesis is associated with impaired liver regeneration in mice. Hepatology 2004;40: 1322-1332.

122 Farrell GC: Probing Prometheus: fat fueling the fire? Hepatology 2004;40:12521255. 
123 Taguchi T, Fukuda M, Ohashi M: Differences in DNA synthesis in vitro using isolated nuclei from regenerating livers of young and aged rats. Mech Ageing Dev 2001;122:141-155.

124 Ikegami T, Nishizaki T, Yanaga K, Shimada M, Kishikawa K, Nomoto K, Uchiyama H, Sugimachi K: The impact of donor age on living donor liver transplantation. Transplantation 2000;70:1703-1707.

125 Abt PL, Mange KC, Olthoff KM, Markmann JF, Reddy KR, Shaked A: Allograft survival following adult-to-adult living donor liver transplantation. Am J Transplant 2004;4:1302-1307.

126 Gaglio PJ, Malireddy S, Levitt BS, LapointeRudow D, Lefkowitch J, Kinkhabwala M, Russo MW, Emond JC, Brown RS Jr: Increased risk of cholestatic hepatitis $\mathrm{C}$ in recipients of grafts from living versus cadaveric liver donors. Liver Transpl 2003;9: 1028-1035.

127 Garcia-Retortillo M, Forns X, Llovet JM, Navasa M, Feliu A, Massaguer A, Bruguera M, Fuster J, Garcia-Valdecasas JC, Rimola $\mathrm{A}$ : Hepatitis C recurrence is more severe after living donor compared to cadaveric liver transplantation. Hepatology 2004;40:699707.
128 Russo MW, Galanko J, Beavers K, Fried MW, Shrestha R: Patient and graft survival in hepatitis $\mathrm{C}$ recipients after adult living donor liver transplantation in the United States. Liver Transpl 2004;10:340-346.

129 Shiffman ML, Stravitz RT, Contos MJ, Mills AS, Sterling RK, Luketic VA, Sanyal AJ, Cotterell A, Maluf D, Posner MP, Fisher RA: Histologic recurrence of chronic hepatitis $\mathrm{C}$ virus in patients after living donor and deceased donor liver transplantation. Liver Transpl 2004;10:1248-1255.

130 Humar A, Horn K, Kalis A, Glessing B, Payne WD, Lake J: Living donor and splitliver transplants in hepatitis $C$ recipients: does liver regeneration increase the risk for recurrence? Am J Transplant 2005;5:399405.

131 Poynard T, Ratziu V, Benmanov Y, Di Martino V, Bedossa P, Opolon P: Fibrosis in patients with chronic hepatitis C: detection and significance. Semin Liver Dis 2000;20: 47-55.

132 Erhardt A, Hassan M, Heintges T, Häussinger D: Hepatitis $\mathrm{C}$ virus core protein induces cell proliferation and activates ERK, JNK, and p38 MAP kinases together with the MAP kinase phosphatase MKP-1 in a HepG2 Tet-Off cell line. Virology 2002;292: 272-284.
33 Lee MN, Jung EY, Kwun HJ, Jun HK, Yu DY, Choi YH, Jang KL: Hepatitis C virus core protein represses the $\mathrm{p} 21$ promoter through inhibition of a TGF- $\beta$ pathway. J Gen Virol 2002;83:2145-2151.

134 Michalopoulos GK: Liver regeneration after partial hepatectomy: critical analysis of mechanistic dilemmas. Am J Pathol 2010; 176:2-13.

135 Fausto N, Riehle KJ: Mechanisms of liver regeneration and their clinical implications. J Hepatobiliary Pancreat Surg 2005; 12:181-189.

136 Nadalin S, Testa G, Malago M, Beste M, Frilling A, Schroeder T, Jochum C, Gerken $\mathrm{G}$, Broelsch CE: Volumetric and functional recovery of the liver after right hepatectomy for living donation. Liver Transpl 2004;10: 1024-1029.

137 Humar A, Kosari K, Sielaff TD, Glessing B, Gomes M, Dietz C, Rosen G, Lake J, Payne WD: Liver regeneration after adult living donor and deceased donor split-liver transplants. Liver Transpl 2004;10:374-378.

138 Haga J, Shimazu M, Wakabayashi G, Tanabe M, Kawachi S, Fuchimoto Y, Hoshino K, Morikawa Y, Kitajima M, Kitagawa Y: Liver regeneration in donors and adult recipients after living donor liver transplantation. Liver Transpl 2008;14:1718-1724. 